\title{
Gender Differences in Adverse Drug Reactions Among Adult Patients Reported to the Iraqi Pharmacovigilance Center
} Areej A. Abdulrazaq", , Dheyaa J. Kadhim* and Manal M. Younus**

\author{
" Department of Clinical Pharmacy, College of Pharmacy, University of Baghdad, Baghdad, Iraq. \\ ${ }^{* *}$ Head of Iraqi Pharmacovigilance Center, Directorate of Technical Affairs, Ministry of Health, Iraq.

\section{Abstract}

For many years it was argued that there may be a gender differences in adverse drug reactions (ADRs). This assumption was based on many possible factors such as hormonal or behavior differences, and it was not clearly identified since the female gender was not preferred to be enrolled in many clinical trials. The primary aim of this study was to assess the extent of possibly relevant gender differences in drug - ADRs regarding causality, severity, preventability, seriousness, expectedness and outcome. While the secondary aim was to assess for which group of drugs and for which ADRs gender differences are identified most often. The study was a retrospective one that depends on processing a specially selected group of data obtained from the Iraqi Pharmacovigilance Center database. The data included consisted of 3833 individual case safety reports sent during the period from $1^{\text {st }}$ January 2017 to $31^{\text {st }}$ December 2019. It was found that the reported adverse drug reactions for females $(60.84$ $\%$ ) were much more than males (39.16\%). In addition, significant differences in age group distribution of adverse drug reactions were found in which females in their reproductive age had more adverse drug reactions while the older adult males were more likely to suffer adverse drug reactions if compared with the same age groups from the opposite gender. The highest type of adverse drug reactions for both genders were those that fall in the skin and subcutaneous tissue disorders (26.4\% in females) and (22.6\% in males) with statically significant difference between the two genders. While the highest group to cause adverse drug reactions was the systemic anti-infective agents with a greater chance 'statistically significant' in females to suffer a side effect from this group of medications $(40.8 \%)$ compared to male gender $(35.5 \%)$. The frequency of serious adverse drug reactions was significantly more prevalent in females $(45.4 \%)$ than for males $(41.3 \%)$ while the fatal outcome was significantly more observed in males $(0.8 \%)$ as compared with females $(0.2 \%)$. The expectedness analysis gave the finding that for each gender, the chances to get an expected ADR were nearly equal.

Keywords: Pharmacovigilance, Adverse drug reactions, Iraqi pharmacovigilance center, Gender differences, Iraq.

$$
\begin{aligned}
& \text { اختلافات الجنسين في الاعراض الجاتبية للأدوية لاى البالغين والتي تم الابلاغ عنها للمركز العراقي } \\
& \text { لليقظة الدوائية }
\end{aligned}
$$

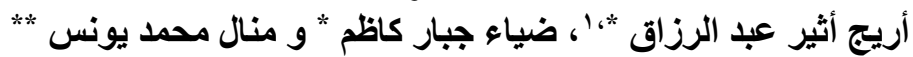

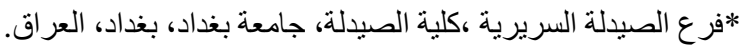

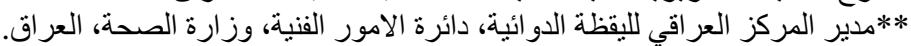

$$
\begin{aligned}
& \text { الخلاصة التركز }
\end{aligned}
$$

${ }^{1}$ Corresponding author E-mail: pharmacologicaleffect@gmail.com

Received: 4/5/2021

Accepted: 11/7/2021

Published Online First: 2021-12-12

Iraqi Journal of Pharmaceutical Science 


\section{Introduction}

From the very early beginning of the human history, human noticed that there were undesirable effects accompanied the benefits while using medications. Many events such as the tragic disaster of thalidomide urged for the development of a well-defined and organized system to monitor drug safety and detect any possible harm to ensure that similar events will never be repeated in the future ${ }^{(1)}$, therefore pharmacovigilance science was developed. Pharmacovigilance (PV) is "the science and activities relating to the detection, assessment, understanding and prevention of adverse effects or any other drug-related problem" as defined by the World Health Organization (WHO) ${ }^{(1)}$. Adverse drug reaction (ADR) is defined by the later as "any noxious or unintended response to a drug, which occurs at doses normally used in man for prophylaxis, diagnosis or therapy of disease, or for modification of physiological function"(2). The spontaneous reporting system which depends on the physician, pharmacist, any health care provider or any other person is the greatest source of newly defined ADRs in recent years. The reasons behind its importance are; its immediate availability after the drug is released to the market ${ }^{(2)}$ and its great ability of detecting rare ADRs that may be missed during the clinical trials ${ }^{(3)}$. This system has its limitations such as the under reporting by health care providers and the high percentage of false positive reports in addition to the low quality of some information reported ${ }^{(2)}$. Other sources of information includes clinical studies, observational studies and the randomized controlled trials ${ }^{(2)}$. Vigiflow which represents the WHO international database of the ADRs reported to the Uppsala monitoring center by the means of spontaneous reports or so called the Individual Case Safety Reports (ICSR) is considered a rich mine of raw information that could be processed in countless ways to obtain various important information ${ }^{(4)}$. In Iraq, there are very small number of studies that make use of the Vigiflow database belonging to the Iraqi Pharmacovigilance Center (IPhvC) that could enrich the Iraqi individuals in addition to the world knowledge about ADRs.

Many studies have found that female gender suffers more ADRs than male gender without any distinct clear reasons ${ }^{(5-8)}$. These variances may be related to hormonal, pharmacodynamics and pharmacokinetic reasons $^{(7,9-11)}$ or may be simply because female gender is consuming more drugs and different medication groups than those used by males ${ }^{(7,9,12-14)}$ or even due to behavioral causes ${ }^{(6,15)}$. The pharmacovigilance parameters and demographic patient's characteristics inspection may give a better idea about ADRs differences between male and female.

The primary aim of this study was to assess the extent of possibly relevant sex differences in drug-ADRs reported to the Iraqi Pharmacovigilance center regarding causality, severity, preventability, seriousness, outcome and expectedness. While the secondary aim was to assess for which drugs and for which ADRs sex differences are identified most often.

\section{Subjects and Method}

This is a pharmacovigilance retrospective study that deals with the data obtained from the online World Health Organization-Uppsala Monitoring Center (WHO-UMC) database known as (Vigiflow) which contain individual case safety reports (ICSRs). Only ICSRs that belong to the Iraqi Pharmacovigilance Center (IPhvC) were accessed after taking the required legal permissions. Reports in the period of three years (from the 1st of January 2017 to the 31st of December 2019) concerning adult patients ( $\geq 18$ years) -which were found to be (7080) reports- were collected and analyzed.

General exclusion criteria that applied were: Reports that not specify the patient's gender (217 reports), reports in which the reporter didn't describe if the ADR was serious or not (311 reports) and reports that didn't mention the action taken to deal with the reported ADR (2487 reports).

Additional specific exclusions were done manually while processing each ICSR separately which were: duplicated reports (32 reports), gender specific ADRs that cannot be compared between both sexes such as vaginal bleeding in female or male impotence (19 reports). gender specific drugs that prescribed for a specific condition related to one gender only such as oral contraceptives (54 reports), reports including vaccines as a suspect of causing the ADR (9 reports), reports that did not include the name of the suspect drug (13 reports), reports that didn't contain the details of the ADR, but only mentioned that there was an ADR that took place (16 reports), reports about blood and auxiliary products such as plasma and packed RBCs (40 reports), reports about the local reactions that appears after doing the allergy tests (44 reports), reports about the intentional over dose or suicidal attempts (2 reports), 3 reports that were excluded because it contained counterfeit medicine and product quality issues. In addition to that, in ICSRs that contain multiple drug suspects or multiple ADRs, some of their drug-ADR combinations (26 combination) were omitted for missing action taken to deal with a drug suspect or for being a gender specific ADR. The resulted study sample was consisted of (3833) reports that have (3972) drugs as suspects, (6153) ADRs and (6407) Drug-ADR combinations to be processed and statistically analyzed.

The differences in the total number of ICSRs, the total number of suspect drugs and the total number of ADRs are due to the fact that in a single ICSR, 
there may be more than one suspect or more than one ADR. The number of Drug-ADR combinations is expected to be the largest number among them because in ICSRs containing several suspects or ADRs, each combination was recorded and analyzed seperatedly.

For each ICSR that included in this study, patient's gender was recorded as it is the most important parameter in this study since the study is depending on finding the differences between the two sexes. For the age of patients, it was recorded and grouped into 3 intervals so that it would be easier to compare and study. These age groups were 18-45 years, $>45$ 65 years and above 65 years' intervals representing female reproductive age, post-menopausal age and elderly age groups respectively.

\section{Adverse drug reactions classification}

The ADRs were classified using the highest level of hierarchy in the Medical Dictionary for Regulatory Activities (Med DRA) which is called the System Organ Classes (SOC) that contain 27 major classes ${ }^{(16) .}$

\section{Suspected drugs classification}

The drugs mentioned in the extracted data were classified according to the Anatomical Therapeutic Chemical (ATC) Classification system, which classify all the medical compounds depending on its different characteristics, it consists of 5 levels. This study concentrates on the $1^{\text {st }}$ level which has fourteen anatomical /pharmacological groups ${ }^{(17) .}$

For the drug combinations that were suspected to cause an ADR, it was recorded and dealt with as a single suspect and it was left without any distinct ATC code, but referred to as 'combination' while doing the drug suspect calculations.

\section{Causality assessment}

Using the WHO-UMC algorithm (18), a causality assessment was done to predict the certainty of association between the administration of a suspected drug in a specific report and the ADR that took place. (Table 1) illustrate the descriptions of each level in the used causality assessment. For this criteria, Drug-ADR combinations were compared between both genders.

Table 1. The WHO-UMC criteria for causality assessment ${ }^{(18)}$

\begin{tabular}{|c|c|}
\hline $\begin{array}{c}\text { Causality term } \\
\text { Assessment }\end{array}$ & Criteria \\
\hline Certain & $\begin{array}{l}\text { Event or laboratory test abnormality with plausible time relation to exposure } \\
\text { - Cannot be explained by diseases or other drugs } \\
\text { - Response to withdrawal plausible (pharmacologically, pathologically) } \\
\text { - Event definitive pharmacologically or phenomenological. } \\
\text { _ Challenge causes definite recurrence. }\end{array}$ \\
\hline Probable/likely & $\begin{array}{l}\text { Event or laboratory test abnormality with reasonable time relation to exposure } \\
\text { - Unlikely to be explained by diseases or other drugs } \\
\text { _ Response to withdrawal clinically reasonable } \\
\text { _ Rechallenge not required or possible. }\end{array}$ \\
\hline Possible & $\begin{array}{l}\text { Event or laboratory test abnormality with reasonable time relation to exposure } \\
\text { _ Could also be explained by diseases or other drugs } \\
\text { _ Information on withdrawal may be lacking or unclear. }\end{array}$ \\
\hline Unlikely & $\begin{array}{l}\text { _ Event or laboratory test abnormality with time relation to exposure that makes } \\
\text { an association improbable (but not impossible) } \\
\text { _ Diseases or other drugs provide plausible explanations. }\end{array}$ \\
\hline $\begin{array}{l}\text { Conditional/ } \\
\text { unclassified }\end{array}$ & $\begin{array}{l}\text { _ Event or laboratory test abnormality } \\
\text { _ More data for proper assessment needed, or } \\
\text { _ Additional data being examined. }\end{array}$ \\
\hline $\begin{array}{l}\text { Unassessable/ } \\
\text { unclassifiable }\end{array}$ & $\begin{array}{l}\text { - Report suggesting an adverse reaction } \\
\text { _ Cannot be judged because information is insufficient or contradictory } \\
\text { _ Data cannot be supplemented or verified. }\end{array}$ \\
\hline
\end{tabular}

\section{Severity}

The modified Hartwig and Seigel criteria were used to assess the severity of the Drug-ADR combinations by categorizing them into 7 ascending levels starting from (level 1) which is mild and requires no interpretations to (level 7) that describes a lethal ADR ${ }^{(19)}$. These levels are explained clearly in (Table 2). 
Table 2, Hartwig's Severity Assessment Scale ${ }^{(19)}$

\begin{tabular}{||l|l|}
\hline \hline Level of severity & \multicolumn{1}{c|}{ The criteria } \\
\hline Level 1 & An ADR occurred but required no change in treatment with the suspected drug \\
\hline Level 2 & $\begin{array}{l}\text { The ADR required that treatment with the suspected drug be held, discontinued, or } \\
\text { otherwise changed. No antidote or other treatment requirement was required. No } \\
\text { increase in length of stay (LOS) }\end{array}$ \\
\hline Level 3 & $\begin{array}{l}\text { The ADR required that treatment with the suspected drug be held, discontinued, or } \\
\text { otherwise changed. AND/ OR an Antidote or other treatment was required. No } \\
\text { increase in LOS }\end{array}$ \\
\hline Level 4 & $\begin{array}{l}\text { Any Level 3 ADR which increases length of stay by at least 1 day. OR The ADR } \\
\text { was the reason for the admission }\end{array}$ \\
\hline Level 5 & Any Level 4 ADR which requires intensive medical care \\
\hline Level 6 & The adverse reaction caused permanent harm to the patient \\
\hline Level 7 & The adverse reaction either directly or indirectly led to the death of the patient 2 \\
\hline \hline
\end{tabular}

\section{Expectedness}

It was evaluated by reviewing the summery of product characteristics (SmPC or SPC). Drug-ADR combinations were categorized into two groups: either 'expected' if the ADR is mentioned previously or 'unexpected' if it is not recorded previously in the $\mathrm{SmPC}^{(20)}$

Preventability: For evaluation of preventability, the modified Schumock and Thornton criteria were applied to each Drug-ADR combination, the criteria

depend on answering 7 questions that discuss several points about the drug safety and conditions of administration with a simple answer of Yes or $\mathrm{No}^{(21)}$. If any of these questions was answered with 'Yes', the ADR would be considered to be preventable. While if all the 7 answers were 'No' it will be recorded as a non-preventable ADR. In case of having any questions with unclear answer while assessing an ICSR, this will be labeled as a possibly preventable ADR (Table 2-3).

Table 3. Schumock and Thornton preventability assessment criteria ${ }^{(21)}$

\begin{tabular}{|c|c|c|c|}
\hline & Question & Yes & 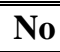 \\
\hline 1 & Was there a history of allergy or previous reaction to the drug? & & \\
\hline 2 & Was the drug involved inappropriate for patient's Clinical Condition? & & \\
\hline 3 & $\begin{array}{l}\text { Was the dose, route, or frequency of administration inappropriate for the } \\
\text { patient's age, weight or disease? }\end{array}$ & & \\
\hline 4 & $\begin{array}{l}\text { Was there any required therapeutic drug monitoring, or other laboratory tests } \\
\text { not performed? }\end{array}$ & & \\
\hline 5 & Was a drug interaction involved in the ADR? & & \\
\hline 6 & Was poor compliance involved in the ADR? & & \\
\hline 7 & Was a toxic serum concentration or a laboratory? monitoring test documented? & & \\
\hline
\end{tabular}

\section{Seriousness}

The seriousness was covered depending on the ICSR seriousness assessment method, which is adopted by the Iraqi pharmacovigilance center
(Figure 1) ${ }^{(3)}$. Relying on the judgment of the person that made the spontaneous report, the ADR that took place was categorized as serious or not. 


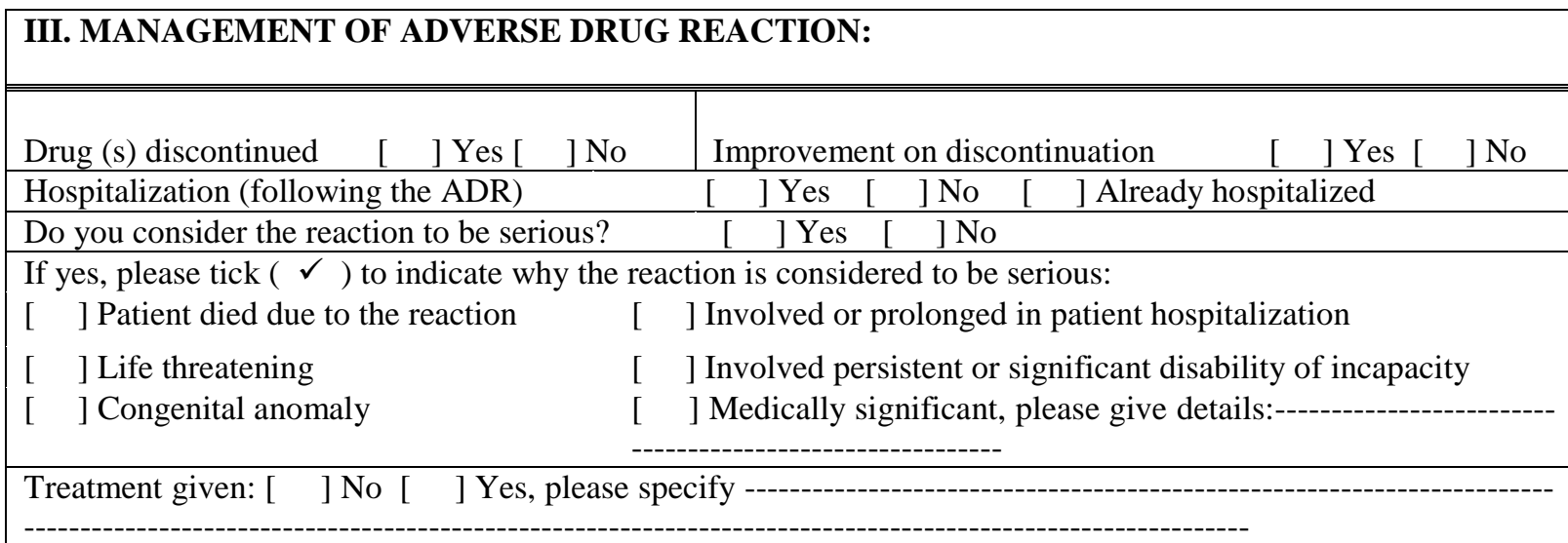

Figure 1.Seriousness assessment in the Iraqi ICSR ${ }^{(3)}$

\section{Action taken}

Information regarding the action taken found in the original Iraqi ICSR (Figure 1) was very important in this study for the identification of the severity level that previously discussed in this paper. Outcome: It can be found on the original Iraqi ICSR on (section II) as shown in (Figure 2) this section will tell the reader if the ADR happened recovered or not, and if the outcome was unknown or fatal. The comparison of this property can give an idea of which gender has better odds in its ADR experience. Ethical approval

This study has been approved by the scientific committee of the University of Baghdad/ College of Pharmacy and the Iraqi Ministry of Health (MOH)/ Department of Research and Development before it was started.

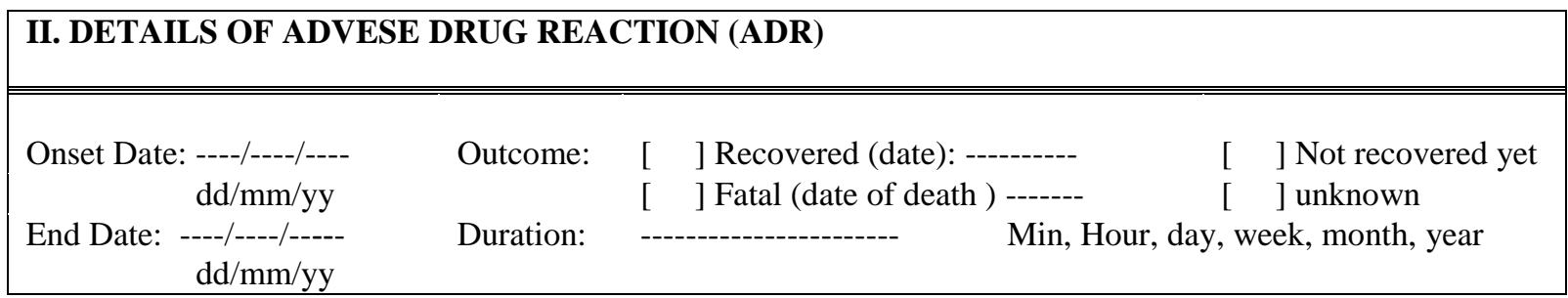

Figure 2. The outcome recording in the Iraqi ICSR

\section{Statistical analysis}

All the data were tabulated and organized using Microsoft Excel 2016. IBM Statistical Package for the Social Sciences (SPSS) program version 26 was used in the statistical calculations. Descriptive statistics such as counting the percentages and frequencies were done. Chi-square test was applied to compare between both genders and search for any significance. Yate's Chi square test was adopted in case of having small values that is below 5 to compare. $\mathrm{P}$ values which is less than 0.05 was considered to be statistically significant.

\section{Results}

From the total of 3833 ICSRs, females had 2332 reports $(60.84 \%)$ while males had 1501 $(39.16 \%)$. Age group distribution demonstrated in
(Table 1) shows that for younger adults that having an age in the array of (18-45 years), the possibility of having an ADR in the female $(63.6 \%)$ is more than that of the male gender $(55.5 \%)$ of the total specific gender population, and this was found to be statistically significant with a $P$ value of $(0.0000005)$. While for the older age group of $(>45-$ 65 years) the chances of males to have an ADR is more $(30.8 \%)$ compared to $(25.9 \%)$ in females, the same was found in the next age group that contains adults of ( $>65$ years) which shows greater chance in male $(13.7 \%)$ than female $(10.5 \%)$ with a $\mathrm{P}$ value of $(0.001$ and 0.002$)$ respectively. 
Table 1. Age group distribution of ADRs

\begin{tabular}{|c|c|c|c|c|}
\hline $\begin{array}{l}\text { Age group } \\
\text { (years) }\end{array}$ & $\begin{array}{l}\text { Number and } \\
\text { percentage of } \\
\text { ICSR }\end{array}$ & $\begin{array}{l}\text { Freq. and } \\
\text { percentages in } \\
\text { female }\end{array}$ & $\begin{array}{c}\text { Freq. and } \\
\text { percentages in } \\
\text { male }\end{array}$ & $\begin{array}{c}\text { Gender } \\
\text { difference } \\
\text { (P value) }\end{array}$ \\
\hline $18-45$ & $2316(60.4 \%)$ & $1483(63.6 \%)$ & $833(55.5 \%)$ & $0.0000005 *$ \\
\hline$>45-65$ & $1068(27.9 \%)$ & $605(25.9 \%)$ & $463(30.8 \%)$ & 0.001* \\
\hline$>65$ & $449(11.7 \%)$ & $244(10.5 \%)$ & $205(13.7 \%)$ & $0.002 *$ \\
\hline Total & $3833(100.0 \%)$ & $2332(100.0 \%)$ & $1501(100.0 \%)$ & \\
\hline
\end{tabular}

"Significant (P-value <0.05) according to Chi square test.

\section{ADRs: Adverse drug reactions, ICSR: Individual Case Safety Report}

Comparing the ADR classes' distribution between both genders depending on the SOC system classification shown in (Table 2) gave the picture that the highest type of ADRs for both genders were those that fall in the skin and subcutaneous tissue disorders (26.4\% in females) and (22.6\% in males) with a statically significant difference between the two genders. The second one was found to be the gastrointestinal disorders but without any statistical significant difference. Respiratory, thoracic and mediastinal disorders came in the third place with $(11.9 \%)$ in females and $(10.1 \%)$ in males which make it a statistically significant difference ( $\mathrm{P}$ value 0.037). The group of disorders that came in the fourth stage is those that fall under the general disorders with the following percentages for female and male $(10.5 \%$ and $11.2 \%)$ respectively, with no significant differences. The nervous system ADRs were having statistically significant differences $(\mathrm{P}$ value 0.02 ), with higher values for the male gender $(10.3 \%)$ while females were $(8.6 \%)$. Other classes had less percentages and no statistically significant differences between both genders.

A statistically significant gender differences were found (Table 3), while testing which medication group -by using the ATC classification- is suspected to be responsible for making the highest number of ADRs in both genders. By taking a deeper look, it was found that the highest group to cause ADRs was the systemic anti-infective agents with a greater chance 'statistically significant' in females to suffer a side effect from this group of medications (40.8\%) compared to male gender $(35.5 \%)$, the cardiovascular group was in the second place with a statistically significant difference toward the male gender $(13.9 \%)$ more than females $(8.5 \%)$. The third was the alimentary tract group with approximately equal chances for both male $(9.4 \%)$ and female $(9.2 \%)$. The nervous system came in the next place with males having $(9.3 \%)$ and females $(8.8 \%)$ so relatively equal chances is present. The fifth group that responsible for making high numbers of ADRs was the antineoplastic and immune-modulating agents, this group was found to cause ADRs in females (9.7\%) more than males (5.8 $\%$ ) with statistically significant differences (P value $0.00001)$.

Another important finding that was recorded in this study is that, males are more prone to have an ADR due to a drug-drug interaction with a statistically significant difference ( $\mathrm{P}$ value 0.03 ). Other groups shown in (Table 3 ) are participating in less extent in the overall percentage of causing ADRs and has no statistically significant differences, except for a group that has low participation but a statistically significant difference which was the systemic hormonal agents that was clearly causing more ADRs in males $(4.1 \%)$ than females $(2.9 \%)(\mathrm{P}$ value 0.047 ). 
Table 2. Distribution of ADR according to the SOC system in both genders.

\begin{tabular}{|c|c|c|c|c|}
\hline SOC system & $\begin{array}{c}\text { Freq. and } \\
\text { percentage of total } \\
\text { reports }\end{array}$ & $\begin{array}{c}\text { Freq. and } \\
\text { percentage in } \\
\text { female }\end{array}$ & $\begin{array}{c}\text { Freq. and } \\
\text { percentage in male }\end{array}$ & $\begin{array}{c}\text { Gender } \\
\text { differences } \\
\text { (P value) }\end{array}$ \\
\hline $\begin{array}{l}\text { Blood and lymphatic } \\
\text { system disorders }\end{array}$ & $39(0.6 \%)$ & $25(0.7 \%)$ & $14(0.6 \%)$ & 0.769 \\
\hline Cardiac disorders & $253(4.1 \%)$ & $150(3.9 \%)$ & $103(4.4 \%)$ & 0.396 \\
\hline $\begin{array}{l}\text { Ear and labyrinth } \\
\text { disorders }\end{array}$ & $38(0.6 \%)$ & $20(0.5 \%)$ & $18(0.8 \%)$ & 0.241 \\
\hline Eye disorders & $118(1.9 \%)$ & $65(1.7 \%)$ & $53(2.3 \%)$ & 0.128 \\
\hline $\begin{array}{l}\text { Gastrointestinal disorders } \\
\text { and Hepatobiliary } \\
\text { disorders }\end{array}$ & $1251(20.3 \%)$ & $755(19.8 \%)$ & $496(21.1 \%)$ & 0.229 \\
\hline $\begin{array}{l}\text { General disorders and } \\
\text { administration site } \\
\text { conditions }\end{array}$ & $663(10.8 \%)$ & $400(10.5 \%)$ & $263(11.2 \%)$ & 0.402 \\
\hline $\begin{array}{l}\text { Immune system } \\
\text { disorders }\end{array}$ & $246(4.0 \%)$ & $155(4.1 \%)$ & $91(3.9 \%)$ & 0.696 \\
\hline $\begin{array}{l}\text { Infections and } \\
\text { infestations }\end{array}$ & $55(0.9 \%)$ & $34(0.9 \%)$ & $21(0.9 \%)$ & 1.000 \\
\hline $\begin{array}{l}\text { Injury, poisoning and } \\
\text { procedural } \\
\text { complications }\end{array}$ & $34(0.6 \%)$ & $17(0.4 \%)$ & $17(0.7 \%)$ & 0.154 \\
\hline Investigations & $89(1.4 \%)$ & $53(1.4 \%)$ & $36(1.5 \%)$ & 0.656 \\
\hline $\begin{array}{l}\text { Metabolism and nutrition } \\
\text { disorders and Endocrine } \\
\text { disorders }\end{array}$ & $116(1.8 \%)$ & $72(1.9 \%)$ & $44(1.9 \%)$ & 0.956 \\
\hline $\begin{array}{l}\text { Musculoskeletal and } \\
\text { connective tissue } \\
\text { disorders }\end{array}$ & $103(1.7 \%)$ & $62(1.6 \%)$ & $41(1.7 \%)$ & 0.731 \\
\hline $\begin{array}{l}\text { Neoplasms benign, } \\
\text { malignant and } \\
\text { Unspecified and } \\
\text { Congenital, familial and } \\
\text { genetic disorders }\end{array}$ & $10(0.2 \%)$ & $5(0.2 \%)$ & $5(0.2 \%)$ & 0.441 \\
\hline $\begin{array}{l}\text { Nervous system } \\
\text { disorders }\end{array}$ & $568(9.2 \%)$ & $326(8.6 \%)$ & $242(10.3 \%)$ & $0.022 *$ \\
\hline $\begin{array}{l}\text { Psychiatric disorders and } \\
\text { Social circumstances }\end{array}$ & $92(1.5 \%)$ & $61(1.6 \%)$ & $32(1.3 \%)$ & 0.372 \\
\hline $\begin{array}{l}\text { Renal and urinary } \\
\text { Disorders and } \\
\text { Reproductive system and } \\
\text { breast disorders }\end{array}$ & $49(0.8 \%)$ & $29(0.8 \%)$ & $20(0.8 \%)$ & 0.702 \\
\hline $\begin{array}{l}\text { Respiratory, thoracic } \\
\text { and mediastinal } \\
\text { disorders }\end{array}$ & $689(11.2 \%)$ & $451(11.9 \%)$ & $238(10.1 \%)$ & $0.037 *$ \\
\hline $\begin{array}{l}\text { Skin and subcutaneous } \\
\text { tissue disorders }\end{array}$ & $1537(25.0 \%)$ & $1005(26.4 \%)$ & $532(22.6 \%)$ & 0.00089* \\
\hline Vascular disorders & $203(3.3 \%)$ & $119(3.1 \%)$ & $84(3.6 \%)$ & 0.339 \\
\hline Total & $6153(100.0 \%)$ & $3804(100.0 \%)$ & $2349(100.0 \%)$ & \\
\hline
\end{tabular}

ADRs: Adverse drug reactions, SOC: System Organ Classes.

*Significant $(\mathrm{P}$-value $<0.05)$ according to Chi square test. 
Table 3. Drug ATC group in both gender

\begin{tabular}{|c|c|c|c|c|}
\hline ATC group & $\begin{array}{c}\text { Frequencies and } \\
\text { percentage }\end{array}$ & $\begin{array}{c}\text { Freq. and } \\
\text { percentage in } \\
\text { female }\end{array}$ & $\begin{array}{c}\text { Freq. and } \\
\text { percentage in Male }\end{array}$ & $\begin{array}{c}\text { Gender } \\
\text { difference (P } \\
\text { value) }\end{array}$ \\
\hline A & $368(9.3 \%)$ & $222(9.2 \%)$ & $146(9.4 \%)$ & 0.853 \\
\hline B & $292(7.4 \%)$ & $173(7.25 \%)$ & $119(7.6 \%)$ & 0.578 \\
\hline C & $423(10.6 \%)$ & $206(8.5 \%)$ & $217(13.9 \%)$ & $0.00000007^{*}$ \\
\hline Comb. $\dagger$ & $33(0.8 \%)$ & $14(0.6 \%)$ & $19(1.2 \%)$ & $0.030^{*}$ \\
\hline D & $35(0.9 \%)$ & $24(1.0 \%)$ & $11(0.7 \%)$ & 0.342 \\
\hline G & $24(0.6 \%)$ & $15(0.6 \%)$ & $9(0.6 \%)$ & 0.862 \\
\hline H & $135(3.4 \%)$ & $71(2.9 \%)$ & $64(4.1 \%)$ & $0.047 *$ \\
\hline J & $1537(38.7 \%)$ & $984(40.8 \%)$ & $553(35.5 \%)$ & $0.00087 *$ \\
\hline L & $324(8.2 \%)$ & $234(9.7 \%)$ & $90(5.8 \%)$ & $0.00001^{*}$ \\
\hline M & $264(6.6 \%)$ & $158(6.5 \%)$ & $106(6.8 \%)$ & 0.749 \\
\hline N & $358(9.0 \%)$ & $213(8.8 \%)$ & $145(9.3 \%)$ & 0.603 \\
\hline P & $5(0.1 \%)$ & $1(0.0 \%)$ & $4(0.3 \%)$ & $0.153 \%$ \\
\hline R & $137(3.4 \%)$ & $79(3.3 \%)$ & $58(3.7 \%)$ & 0.447 \\
\hline S & $23(0.6 \%)$ & $12(0.5 \%)$ & $11(0.7 \%)$ & 0.396 \\
\hline V & $14(0.4 \%)$ & $8(0.3 \%)$ & $6(0.4 \%)$ & 0.780 \\
\hline Total & $3972(100.0 \%)$ & $2414(100.0 \%)$ & $1558(100.0 \%)$ & \\
\hline
\end{tabular}

ATC; Anatomical Therapeutic Chemical. A; Alimentary tract and metabolism. B; Blood and blood forming organ. C; Cardiovascular system. D; Dermatological agents. G; Genitourinary system and sex hormones. H; Systemic hormonal preparations. J; Anti-infective for systemic use. L; Antineoplastic and immune modulating agents. M; Musclo-skeletal system. N; Nervous system. P; Antiparasitic agents, insecticides and repellants. R; Respiratory system. S; Sensory organs. V; Various.

* Significant (P-value <0.05) according to Chi square test.

$\uparrow$ Comb. Refers to the ADRs caused by drug combinations (Drug-Drug interactions)

\$ Yates' Chi square test was adopted because of the small values (below 5).

When comparing the seriousness of ADRs between both genders (Table 4), a statistically significant difference (P value 0.001) was found which indicate that the reported ADRs were considered to be more serious in female $(45.4 \%)$ than for males $(41.3 \%)$ according to the initial reporter judgment.

Table 4. Seriousness of ADR in both gender

\begin{tabular}{||c|c|c|c|c||}
\hline \hline Seriousness & $\begin{array}{c}\text { Freq. and } \\
\text { percentage in total } \\
\text { ICSR }\end{array}$ & $\begin{array}{c}\text { Female frequency } \\
\text { and percentage }\end{array}$ & $\begin{array}{c}\text { Male frequency and } \\
\text { percentage }\end{array}$ & $\begin{array}{c}\text { Gender } \\
\text { difference }(\mathrm{P} \\
\text { value })\end{array}$ \\
\hline No & $3456(56.2 \%)$ & $2076(54.6 \%)$ & $1380(58.7 \%)$ & \multirow{2}{*}{$\mathbf{0 . 0 0 1 *}$} \\
\hline Yes & $2697(43.8 \%)$ & $1728(45.4 \%)$ & $969(41.3 \%)$ & \\
\hline Total & $6153(100.0 \%)$ & $3804(100.0 \%)$ & $2349(100.0 \%)$ & \\
\hline
\end{tabular}

* Significant $(\mathrm{P}$-value <0.05) according to Chi square test.

Studying the outcome of ADRs in both genders shown in (Table 5), demonstrates that there were statistically significant differences. The fatal outcome was more observed in male gender $(0.8 \%)$ as compared with females $(0.2 \%)$. The recovery was more detected in females $(77.1 \%)$ than males $(74.1$ $\%)$ while the unknown outcome was recorded more frequently in males $(13.2 \%)$ than female $(10.4 \%)$. Other outcome subgroups that include the recovery with sequelae, ADRs that not recovered till the time of reporting and the ADRs that still under the recovery phase were without any statistically significance differences. 
Table 5. Outcome of the ADR for each gender.

\begin{tabular}{||l|c|c|c|c||}
\hline \multicolumn{1}{|c|}{ Outcome } & $\begin{array}{c}\text { Freq. and } \\
\text { percentage in } \\
\text { total }\end{array}$ & $\begin{array}{c}\text { Freq. and } \\
\text { percentage in } \\
\text { female }\end{array}$ & $\begin{array}{c}\text { Freq. and } \\
\text { percentage in } \\
\text { male }\end{array}$ & $\begin{array}{c}\text { Gender } \\
\text { difference } \\
\text { (P value) }\end{array}$ \\
\hline Fatal & $24(0.4 \%)$ & $6(0.2 \%)$ & $18(0.8 \%)$ & $0.00019^{*}$ \\
\hline Not recovered & $524(8.5 \%)$ & $324(8.5 \%)$ & $200(8.5 \%)$ & 1.000 \\
\hline Recovered & $4673(75.9 \%)$ & $2933(77.1 \%)$ & $1740(74.1 \%)$ & $0.006^{*}$ \\
\hline $\begin{array}{l}\text { Recovered with } \\
\text { sequelae }\end{array}$ & $20(0.3 \%)$ & $14(0.4 \%)$ & $6(0.3 \%)$ & 0.451 \\
\hline Recovering & $208(3.4 \%)$ & $132(3.5 \%)$ & $76(3.2 \%)$ & 0.620 \\
\hline Unknown & $704(11.4 \%)$ & $395(10.4 \%)$ & $309(13.2 \%)$ & $0.0009 *$ \\
\hline Total & $6153(100 \%)$ & $3804(100 \%)$ & $2349(100 \%)$ & \\
\hline
\end{tabular}

* Significant (P-value <0.05) according to Chi square test.

The causality assessment (Table 6) showed that the major category found in the study sample was the probable which counted for $(66.1 \%)$ of the total number of Drug-ADR combinations followed by the possible category $(28 \%)$. There were significant differences in the probable and the possible categories only. Females ADRs, according to these findings, are more obvious and related easier to the suspect drug because the probable category has higher percentage in the female gender $(68.5 \%)$ compared with male gender $(62.2 \%)$, while the possible category has higher male findings $(31.4 \%)$ compared with the females $(25.8 \%)$. For other categories, values were closely the same without any statistically significant differences.

Table 6. Causality assessment of ADR.

\begin{tabular}{||c|c|c|c|c|}
\hline $\begin{array}{c}\text { Causality by WHO } \\
\text { method }\end{array}$ & $\begin{array}{c}\text { Freq. and } \\
\text { percentage in total } \\
\text { reports }\end{array}$ & $\begin{array}{c}\text { Female frequency } \\
\text { and percentage }\end{array}$ & $\begin{array}{c}\text { Male frequency } \\
\text { and percentage }\end{array}$ & $\begin{array}{c}\text { Gender } \\
\text { difference }(\mathrm{P} \\
\text { value })\end{array}$ \\
\hline Certain & $15(0.2 \%)$ & $9(0.2 \%)$ & $6(0.2 \%)$ & 0.882 \\
\hline Conditional & $265(4.1 \%)$ & $161(4.1 \%)$ & $104(4.3 \%)$ & 0.710 \\
\hline Possible & $1791(28.0 \%)$ & $1023(25.8 \%)$ & $768(31.4 \%)$ & $\mathbf{0 . 0 0 0 0 0 1 2} *$ \\
\hline Probable & $4234(66.1 \%)$ & $2714(68.5 \%)$ & $1520(62.2 \%)$ & $\mathbf{0 . 0 0 0 0 0 0 2} *$ \\
\hline Unlikely & $102(1.6 \%)$ & $55(1.4 \%)$ & $47(1.9 \%)$ & 0.097 \\
\hline Total & $6407(100 \%)$ & $3962(100 \%)$ & $2445(100 \%)$ & \\
\hline
\end{tabular}

*Significant (P-value <0.05) according to Chi square test.

The evaluation of severity criteria shows that most of the reported ADRs were considered to be from Level 2 of the Hartwig's severity assessment scale which represents ADRs that needs only to discontinue administrating of the suspect agent as a management to the harm ensued. There were statistically significant differences between both genders in two levels of severity only. These were the third level which refers to the ADRs that need to stop giving suspect drugs in addition to the use of a drug or an antidote for treating the resulted harm, this level was significantly higher in female gender $(9.2 \%)$ compared to male $(7.2 \%)$. The other level that also showed a statistically significant difference was the seventh level, ADRs that cause death of the patient directly or indirectly, which was found to be higher in male gender $(0.8 \%)$ than female $(0.2 \%)$ (Table 7). 
Table 7. Severity of ADR in both gender

\begin{tabular}{|c|c|c|c|c||}
\hline $\begin{array}{c}\text { Severity } \\
\text { level }\end{array}$ & $\begin{array}{c}\text { Freq. and percentage in all } \\
\text { ICSR }\end{array}$ & $\begin{array}{c}\text { Female freq. and } \\
\text { percentage }\end{array}$ & $\begin{array}{c}\text { Male freq. and } \\
\text { percentage }\end{array}$ & $\begin{array}{c}\text { Gender difference } \\
\text { (P value) }\end{array}$ \\
\hline Level 1 & $791(12.3 \%)$ & $474(12.0 \%)$ & $317(13.0 \%)$ & 0.236 \\
\hline Level 2 & $4211(65.7 \%)$ & $2600(65.6 \%)$ & $1611(65.9 \%)$ & 0.826 \\
\hline Level 3 & $540(8.4 \%)$ & $364(9.2 \%)$ & $176(7.2 \%)$ & $\mathbf{0 . 0 0 5 3} *$ \\
\hline Level 4 & $785(12.3 \%)$ & $481(12.1 \%)$ & $304(12.4 \%)$ & 0.727 \\
\hline Level 5 & $40(0.6 \%)$ & $26(0.7 \%)$ & $14(0.6 \%)$ & 0.680 \\
\hline Level 6 & $12(0.2 \%)$ & $9(0.2 \%)$ & $3(0.1 \%)$ & $0.520 \ddagger$ \\
\hline Level 7 & $28(0.4 \%)$ & $8(0.2 \%)$ & $20(0.8 \%)$ & $\mathbf{0 . 0 0 0 2} *$ \\
\hline Total & $6407(100 \%)$ & $3962(100 \%)$ & $2445(100 \%)$ & \\
\hline
\end{tabular}

*Significant (P-value <0.05) according to Chi square test.

† Yates' Chi square test was adopted because of the small values (below 5).

Females and males had no statistically significant differences in the preventability patterns of ADRs in both possibly preventable and preventable ADRs, while the non-preventable subgroup were totally not found in the study population because some of the important information needed to mark the cases as a non-preventable ADR were not recorded in the ICSRs. The resulted findings are recorded in (Table 8).

Table 8. Preventability of ADR in both sex.

\begin{tabular}{||l|c|c|c|c||}
\hline Preventability of ADR & $\begin{array}{c}\text { Total report freq. } \\
\text { and percentage }\end{array}$ & $\begin{array}{c}\text { Female freq. and } \\
\text { percentage }\end{array}$ & $\begin{array}{c}\text { Male freq. and } \\
\text { percentage }\end{array}$ & $\begin{array}{c}\text { Gender } \\
\text { difference } \\
\text { (P value) }\end{array}$ \\
\hline Possibly preventable & $6170(96.3 \%)$ & $3823(96.5 \%)$ & $2347(96.0 \%)$ & \multirow{2}{*}{0.303} \\
\cline { 1 - 4 } Preventable & $237(3.7 \%)$ & $139(3.5 \%)$ & $98(4.0 \%)$ & \\
\hline Total & $6407(100 \%)$ & $3962(100 \%)$ & $2445(100 \%)$ & \\
\hline
\end{tabular}

The expectedness analysis showed in (Table 9) gave the finding that for each gender the expectedness of

ADRs were nearly equal.

Table 9: Expectedness of ADR for each gender

\begin{tabular}{|c|c|c|c|c|}
\hline \hline Expected ADR & $\begin{array}{c}\text { Freq. and percentage } \\
\text { in total }\end{array}$ & $\begin{array}{c}\text { Freq. and percentage } \\
\text { in female }\end{array}$ & $\begin{array}{c}\text { Freq. and percentage } \\
\text { in male }\end{array}$ & $\begin{array}{c}\text { Gender } \\
\text { difference } \\
\text { (P value) }\end{array}$ \\
\hline No & $2070(32.3 \%)$ & $1277(32.2 \%)$ & $793(32.4 \%)$ & \multirow{2}{*}{0.867} \\
\hline Yes & $4337(67.7 \%)$ & $2685(67.8 \%)$ & $1652(67.6 \%)$ & \\
\hline Total & $6407(100 \%)$ & $3962(100 \%)$ & $2445(100 \%)$ & \\
\hline
\end{tabular}

\section{Discussion}

This study revealed the characteristics of the reported ADRs to the IPhvC. Some of the obtained results were nearly similar to previous readings from different countries and the other findings were unique in the studied population. The predominance of female gender in the total number of ICSRs is an expected result that resembles many previous studies ${ }^{(6,15,22,23)}$. This is a multifactorial fact with no clear explanation, that may be due to pharmacological, biological, social and behavioral differences between both genders(6-8). During their reproductive age, females are more susceptible to have ADRs than males from the same age group. This finding cannot be explained by female use of extra -gender specific- drugs such as oral contraceptives since cases containing contraceptive suspects were excluded from the study sample, neither could be related to the total number of population of each gender since it is approximately equal in our country according to official publications ${ }^{(24)}$. This finding is similar to many previous studies such as; the sex related Vigibase global data analysis of the last 50 years(23) and the Tran et al work which analyzed 10 years data collected from "Glaxo Wellcome-Sunnybrook Drug Safety Clinic" records in Canada searching for gender differences $\left({ }^{6}\right)$. This age group variation could be due to the fact that females during their reproductive age seek more medical attention and had twice more doctor visits than males and are more likely to report any medical concerns and look

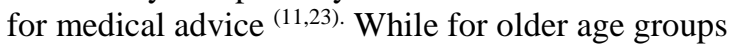
( $>45-65$ years) and (> 65 years), the male gender was recorded to have more ADRs than females. This could be because males were found to have greater hospital stays in the ages above 44 years which might mean more medications and complications (11). The biggest group of drugs that found to cause 
ADRs were antibiotics for systemic use and it was higher in the females. A possible explanation of this finding is the increasing number of cesarean section operations in Iraq in the last years(25) which has led to the increasing use of antibiotics for prophylactic reasons. While the cardiovascular system agents were higher in the male gender. This could be reasonable if taking in consideration that; males are diagnosed with cardiovascular diseases more often than females ${ }^{(26),}$ and the prevalence of both stroke and heart disease is higher in men worldwide ${ }^{(27)}$. This will result in more male gender related consumption of cardiovascular agents ${ }^{(28)}$ and as a result, more ADRs will appear and be reported for those agents.

The observed differences in the SOC systems of ADRs distribution in both genders could be explained by the presence of variances in the used medications by each gender (28) which has led to the appearance of different sorts of ADRs. In the current study, the frequency of serious ADRs was significantly more prevalent in females than for males (Table 4), these results contradict the global analysis of the Vigiflow database which found that males had more serious ADRs than females (23). Also, it was found that females were taking treatments for the ADRs more than males and males had a higher mortality due to ADRs than females. These findings were similar to the global review of Vigiflow database ${ }^{(23)}$. The higher mortality in male gender could be explained by three reasons identified here which are: males not tend to seek medical help early during their ADR experience as women do ${ }^{(23)}$, they tend to use different classes of medications (28) in addition to that, they suffer from ADRs in older age groups (Table 1). The males had less clear ADRs outcome since more females are reported to be recovered from their ADRs and more males had unknown outcome (Table 5), also the causality assessment for the males are less linked to the use of medications than the female gender (Table 6). The causality assessment may explain, for some extent, the outcome results of the current study where the ADRs are more clearly linked to medications used by females so it is easier to manage these reactions either by giving treatment or by stop giving the causative drugs while in male gender the causality is less obvious. For the expectedness and the preventability, there were no differences between both genders.

Although the current study has a large sample size over a relatively extended period of time, it has several limitations such as its dependence on the spontaneous reports only which means a lot of important ADRs that occur in practice and passed without reporting were not identified here. The study is of a retrospective type that restricted by the available information only which caused the exclusion of numerous reports missing essential data and that may affect the study statistical results. Also, the available reported data did not have the same quality as they are disclosed by different sources and qualifications which may lead to bias.

\section{Conclusions and Recommendations}

In conclusion, the current study showed possibly relevant differences between males and females in the ADRs spontaneously reported to the Iraqi Pharmacovigilance Center indicating that gender may be a risk factor for (development of ADRs for some class of drugs, some types of ADRs, seriousness of ADRs, as well as the outcome of these ADRs). Further work is required to elucidate the mechanisms explaining the differences observed between male and female patients. In addition, more efforts should be done by the Iraqi Pharmacovigilance Center to improve the quality of individual case safety reports.

\section{References}

1. Talbot J, Aronson JK. Stephens' Detection and Evaluation of Adverse Drug Reactions: Principles and Practice. Stephens' Detection and Evaluation of Adverse Drug Reactions: Principles and Practice, Sixth Edition. 2012.

2. WHO, MSH, USAID. Drug and Therapeutics Committee Training Course: Assessing and Managing Medicine Safety. 2007;Drug and $\mathrm{T}: 1-24 . \quad$ Available from: http://www.who.int/medicines/technical_briefi ng/tbs/04-PG_Dug-Safety_final-08.pdf?ua=1

3. Health MOF. GUIDELINES FOR THE IRAQI PHARMACOVIGILANCE SYSTEM ( IPhvC ). 2012;1-34.

4. Uppsala Monitoring Centre. Guideline for using VigiBase data in studies. 2016; Version 2(9):19. Available from: http://www.whoumc.org/graphics/28461.pdf

5. Zopf Y, Rabe C, Neubert A, Janson C, Brune K, Hahn EG, et al. Gender-based differences in drug prescription: Relation to adverse drug reactions. Pharmacology. 2009;84(6):333-9.

6. Tran C, Knowles SR, Liu BA, Shear NH. Gender differences in adverse drug reactions. J Clin Pharmacol. 1998;38(11):1003-9.

7. Montastruc JL, Lapeyre-Mestre M, Bagheri H, Fooladi A. Gender differences in adverse drug reactions: Analysis of spontaneous reports to a Regional Pharmacovigilance Centre in France. Fundam Clin Pharmacol. 2002;16(5):343-6.

8. Ozcan G, Aykac E, Kasap Y, Nemutlu NT, Sen E, Aydinkarahaliloglu ND. Adverse Drug Reaction Reporting Pattern in Turkey: Analysis of the National Database in the Context of the First Pharmacovigilance Legislation. Drugs Real World Outcomes. 2016;3(1):33-43.

9. Franconi F, Brunelleschi S, Steardo L, Cuomo V. Gender differences in drug responses. Pharmacol Res. 2007;55(2):81-95.

10. Anderson GD. Chapter 1 Gender Differences in 
Pharmacological Response. Int Rev Neurobiol. 2008;83(08):1-10.

11. Alomar MJ. Factors affecting the development of adverse drug reactions (Review article). Saudi Pharm J [Internet]. 2014;22(2):83-94. Available from: http://dx.doi.org/10.1016/j.jsps.2013.02.003

12. Rademaker M. American Journal of Clinical Dermatology 2: 349-351, No. 6, 2001. Curr Opin Am J Clin Dermatol [Internet]. 2001;2(6):349-51. Available from: https://linkspringer-

com.apollo.worc.ac.uk/content/pdf/10.2165\%2 F00128071-200102060-

00001.pdf\%0Ahttps://link.springer.com/conten t/pdf/10.2165\%2F00128071-20010206000001.pdf

13. Zucker I, Prendergast BJ. Sex differences in pharmacokinetics predict adverse drug reactions in women. Biol Sex Differ. 2020;11(1):32.

14. Franconi F, Campesi I, Occhioni S, Antonini P, Murphy MF. Sex and gender in adverse drug events, addiction, and placebo. Handb Exp Pharmacol. 2012;214:107-26.

15. de Vries ST, Denig P, Ekhart C, Burgers JS, Kleefstra N, Mol PGM, et al. Sex differences in adverse drug reactions reported to the National Pharmacovigilance Centre in the Netherlands: An explorative observational study. Br J Clin Pharmacol. 2019;85(7):1507-15.

16. medDRA. 27th System Organ Class [Internet]. [cited 2021 May 3]. Available from: https://www.meddra.org/About MedDRA / Evolution / 27th-system-organ-class

17. Sataloff RT, Johns MM, Kost KM. Guidlines for ATC classification and DDD assignment / 2021. 2021.

18. MHRA. WHO Causality assessment. Good Pharmacovigil Pract Guid. 2009;(3):39.

19. Hartwig SC, Siegel J, Schneider PJ. Preventability and severity assessment in reporting adverse drug reactions. Am J Hosp Pharm [Internet]. 1992 Sep 1;49(9):2229-32. Available https://doi.org/10.1093/ajhp/49.9.2229

20. Petrova G, Stoimenova A, Dimitrova M,
Kamusheva M, Petrova D, Georgiev O. Assessment of the expectancy, seriousness and severity of adverse drug reactions reported for chronic obstructive pulmonary disease therapy. SAGE Open $\quad 2017$ Dec;5:205031211769040.

21. Schumock GT, Thornton JP. Focusing on the preventability of adverse drug reactions. Vol. 27, Hospital Pharmacy. 1992. p. 538.

22. Sundaran $S$, Udayan $A$, Hareendranath $K$, Eliyas B, Ganesan B, Hassan A, et al. Study on the Classification, Causality, Preventability and Severity of Adverse Drug Reaction Using Spontaneous Reporting System in Hospitalized Patients. Pharmacy. 2018;6(4):108.

23. Watson S, Caster O, Rochon PA, den Ruijter H. Reported adverse drug reactions in women and men: Aggregated evidence from globally collected individual case reports during half a century. EClinicalMedicine [Internet]. 2019;17:100188. Available from: https://doi.org/10.1016/j.eclinm.2019.10.001

24. United Nations. World Population Prospects 2019 [Internet]. [cited 2021 Jun 6]. Available from:

https://population.un.org/wpp/Download/Stand ard/Population/

25. Shabila NP. Rates and trends in cesarean sections between 2008 and 2012 in Iraq. BMC Pregnancy Childbirth [Internet]. 2017;17(1):49. Available from: http://dx.doi.org/10.1186/s12884-016-1211-6

26. Pilote L, Dasgupta K, Guru V, Humphries KH, McGrath J, Norris C, et al. A comprehensive view of sex-specific issues related to cardiovascular disease. CMAJ. 2007;176(6).

27. Bots SH, Groepenhoff F, Eikendal ALM, Tannenbaum C, Rochon PA, Regitz-Zagrosek $\mathrm{V}$, et al. Adverse Drug Reactions to GuidelineRecommended Heart Failure Drugs in Women: A Systematic Review of the Literature. JACC Hear Fail. 2019;7(3):258-66.

28. Putignano D, Bruzzese D, Orlando V, Fiorentino D, Tettamanti A, Menditto E. Differences in drug use between men and women: An Italian cross sectional study. BMC Womens Health. 2017;17(1):1-7.
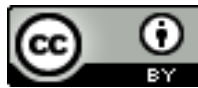

Baghdad Iraqi Journal Pharmaceutical Sciences by bijps is licensed under a Creative Commons Attribution 4.0 International License. Copyrights@ 2015 College of Pharmacy - University of Baghdad. 